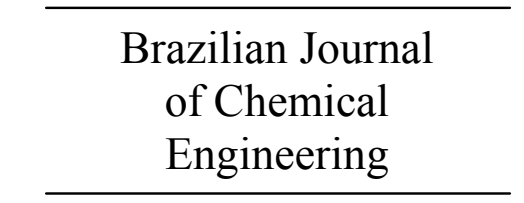

ISSN 0104-6632

Printed in Brazil

www.abeq.org.br/bjche

Vol. 29, No. 03, pp. 483 - 493, July - September, 2012

\title{
RENEWABLE RESOURCES FOR BIOSURFACTANT PRODUCTION BY Yarrowia lipolytica
}

\author{
G. C. Fontes, N. M. Ramos, P. F. F. Amaral, M. Nele and M. A. Z. Coelho* \\ Escola de Química/Universidade Federal do Rio de Janeiro, Centro de Tecnologia, B1. E, Lab. 103, \\ Phone: + (55) (21) 25627564, Fax: + (55) (21) 25627622, Cidade Universitária, \\ 21949-900, Rio de Janeiro - RJ, Brazil. \\ E-mail: alice@eq.ufrj.br
}

(Submitted: January 6, 2012 ; Revised: February 26, 2012 ; Accepted: March 16, 2012)

\begin{abstract}
In this work, the production of a biosurfactant synthesized by Yarrowia lipolytica using different renewable resources as carbon source was investigated. Crude glycerol, a biodiesel co-product, and clarified cashew apple juice (CCAJ), an agroindustrial residue, were applied as feedstocks for the microbial surfactant synthesis. The microorganism was able to grow and produce biosurfactant on CCAJ and crude glycerol, achieving maximum emulsification indexes of $68.0 \%$ and $70.2 \%$ and maximum variations in surface tension of $18.0 \mathrm{mN} \cdot \mathrm{m}^{-1}$ and $22.0 \mathrm{mN} . \mathrm{m}^{-1}$, respectively. Different organic solvents (acetone, ethyl acetate and chloroform-methanol) were tested for biosurfactant extraction. Maximum biosurfactant recovery was obtained with chloroform-methanol (1:1), reaching 6.9 g.L $\mathrm{L}^{-1}$ for experiments using CCAJ and 7.9 g.L $\mathrm{L}^{-1}$ for media containing crude glycerol as carbon source. The results herein obtained indicate that CCAJ and the co-product of biodiesel production are appropriate raw materials for biosurfactant production by Y. lipolytica. Keywords: Biosurfactant; Yeast; Surface tension; Glycerol; Cashew apple juice.
\end{abstract}

\section{INTRODUCTION}

Biosurfactants are amphiphilic compounds produced by living organisms, mostly on microbial cell surfaces or excreted extracellularly, and contain hydrophobic and hydrophilic moieties that reduce surface tension and interfacial tension at the surface and interface, respectively (Muthusamy et al., 2008). Interest in biosurfactants has increased considerably in recent years, as they are potential candidates for many commercial applications in the petroleum, pharmaceutical, biomedical and food processing industries (Mulligan, 2004).

Most of the surface active compounds currently in use are synthesized chemically. However, microbially produced surfactants offer several advantages over their chemical counterparts, such as biodegradability, low toxicity and production from renewable substrates (Mercade and Mansera, 1994). Although biosurfactants exhibit such important advantages, they have not yet been employed extensively in industry because of relatively high production costs. One possible strategy for reducing costs is the utilization of alternative substrates such as agroindustrial wastes (Maneerat, 2005). The choice of inexpensive raw materials is important to the overall economy of the process because they account for $50 \%$ of the final product cost (Makkar and Cameotra, 1997).

In the literature, different renewable resources and agro industrial residues have been used for biosurfactant production. Molasses (Makkar and Cameotra, 1997), cassava wastewater (Nitschke and Pastore, 2002), olive oil mill effluent (Mercade and Mansera, 1994), animal fat (Desphande and Daniels, 1995), weathered diesel oil (Mariano et al., 2008 and Sousa et al., 2012), waste frying oils (Vedaraman

*To whom correspondence should be addressed 
and Venkatesh, 2011), distillery residues and whey (Dubey and Juwarkar, 2001) have been studied as low cost substrates for microbial growth and biosurfactant production.

Cashew apple is a tropical pseudofruit in which the real fruit is a nut, a well-known product around the world (Campos et al., 2002). Internal and external market consumption of cashew nuts, in the year of 2004 , was about 232,000 t. However, only $12 \%$ of the total peduncle is processed. In the northeast of Brazil, the cashew agroindustry has an outstanding role in the local economy. However, only a small part of the pseudofruit produced is used industrially and the amount wasted, approximately $94.0 \%$, presents high potential as a fermentation medium, since it is rich in carbohydrate, fibers, vitamins and minerals salts (Rocha et al., 2007).

The use of cashew apple juice was evaluated by Honorato et al. (2007) to produce high added value products such as dextran, lactic acid, mannitol and oligosaccharides. Rocha et al. (2006) studied cashew apple juice (CAJ) as a fermentation medium for biosurfactant production by Acinetobacter calcoaceticus. The microorganism was able to grow and produce biosurfactant on $\mathrm{CAJ}$, reducing the surface tension of the medium from 72 to $62 \mathrm{mN} \cdot \mathrm{m}^{-1}$. The biosurfactant also achieved a maximum emulsion index of $58.8 \%$ for kerosene. Rocha et al. (2009) developed a growth medium made of mineral medium and yeast extract containing clarified cashew apple juice as carbon source and employed it to cultivate an isolate of Bacillus subtilis LAMI008 and produce surfactin. The biosurfactant produced (3.5 mg..$^{-1}$ ) was capable of emulsifying kerosene, achieving an emulsification index of $65 \%$ and the surface tension decreased from 58.95 to $38.10 \mathrm{mN} . \mathrm{m}^{-1}$.

Another potential renewable source for microbial production of surfactant is glycerol from biodiesel production. Because biodiesel production is increasing exponentially, the crude glycerol generated by the transesterification of vegetable oils is also being produced in large quantity. The current annual amount of glycerin arising from this biodiesel production amounts to some 1.9 Mton and will continue to rise proportionally. Nowadays, the world market for pure glycerol of high quality for industrial applications (chemical and pharmaceutical) only amounts to some $0.9-1.0$ Mton per year (2007) (Hoogendoorn et al., 2007). Therefore, either new applications for glycerin need to be developed and/or the existing pathways need to be expanded. The use of crude glycerol as feedstock to obtain biotechnology products, such as biosurfactants, can alleviate many industrial process waste management problems. Glycerol has been successfully used as a water soluble carbon source for different microbial productions (Amaral et al., 2009).

Morita et al. (2007) evaluated glycerol microbial conversion into biosurfactant (glycolipids) by Pseudozyma antarctica JCM 10317, observing a glycolipid production of 16.3 g.. $\mathrm{L}^{-1}$ in a fed batch operation with glycerol as carbon source. Ciapina et al. (2007) evaluated the use of pure glycerol as carbon source for biosurfactant production by Rhodococcus erythropolis; after 51 cultivation hours, 1.7 g. $\mathrm{L}^{-1}$ of biosurfactant were obtained.

Ashby et al. (2005) compared pure glycerol with biodiesel production residue as carbon sources for sophorolipid production by Candida bombicola. Fermentations with pure glycerol resulted in 9.0 g..$^{-1}$ of sophorolipids, while fermentation with biodiesel residue provided a biosurfactant production of 6.0 g. $1^{-1}$.

Many microorganisms are able to metabolize glycerol, like the yeast $Y$. lipolytica (Fontes et al., 2010) and different strains of the bacterium Pseudomonas aeruginosa (Wu et al., 2008; Wei et al., 2005). Studies have shown that $Y$. lipolytica is capable of producing some interesting compounds from raw glycerol, such as biosurfactants and organic acids (Fontes et al., 2010; Papanikolaou and Aggelis, 2003).

This paper aims to contribute to the use of industrial byproducts as carbon and energy sources for cultivation of $Y$. lipolytica and production of biosurfactant. Crude glycerol, a biodiesel by-product, and clarified cashew apple juice (CCAJ), an agroindustrial residue, were applied as feedstocks for microorganism growth and microbial synthesis of the surfactant.

\section{MATERIALS AND METHODS}

\section{Microorganism and Inoculum}

A wild type strain of Yarrowia lipolytica (IMUFRJ 50682) was employed (Haegler and Mendonça-Haegler, 1981) and kept at $4{ }^{\circ} \mathrm{C}$ on YPDagar medium (w/p: yeast extract (Oxoid) $1.0 \%$, peptone (Oxoid), 0.6\%; glucose (Reagen), 2.0\%, agar (Reagen), 2.5\%). For inoculum conditions, cells were cultivated at $28{ }^{\circ} \mathrm{C}$ in a rotary shaker at $160 \mathrm{rpm}$, in $500 \mathrm{ml}$ shake flasks containing $200 \mathrm{ml}$ of YPD medium. After $48 \mathrm{~h}$ of cultivation, these cells were used in sufficient amount to inoculate $1 \mathrm{mg}$ of cells per $\mathrm{ml}$ of biosurfactant production media. 
Culture Medium and Culture Conditions

\section{Clarified Cashew Apple Juice (CCAJ)}

CCAJ was obtained through a mechanical process and clarified as described by Honorato et al. (2007). The $\mathrm{pH}$ of CCAJ was adjusted to 7.0 with $0.5 \mathrm{M}$ $\mathrm{NaOH}$ and then filtered through a $0.45-\mu \mathrm{m}$ membrane (Millipore Corp.) and exposed to ultraviolet radiation $\left(6.000 \mu \mathrm{W} \cdot \mathrm{s} / \mathrm{cm}^{2}\right)$ for $1 \mathrm{~h}$ for sterilization in order to avoid loss of heat-labile components. Table 1 shows the CCAJ composition (Rocha et al., 2007) and Table 2 shows the different media evaluated in this study. The CCAJ was diluted one or ten times with distilled water and ammonium sulfate was used as nitrogen source. Biosurfactant production was carried out in $1000 \mathrm{ml}$ shake flasks, containing $500 \mathrm{ml}$ of the culture medium, in a rotary shaker at $28{ }^{\circ} \mathrm{C}$ and $250 \mathrm{rpm}$ for $96 \mathrm{~h}$. Samples were collected at time-defined intervals of 24 hours and submitted to analysis for determination of reducing sugars, cell concentration, emulsification index and surface tension.

\section{Glycerin}

Glycerol P.A (Vetec Química, S/A) and the glycerin phase obtained from the transesterification of castor oil by methanol in alkaline medium $(\mathrm{NaOH})$ were used for biosurfactant production by $Y$. lipolytica. The experiments were performed with crude and hydrolyzed glycerin. The glycerin used in this work was the co-product of biodiesel production, resulting from the transesterification of castor bean oil by methanol in alkaline medium $(\mathrm{NaOH})$. Both materials from biodiesel production were prepared following the procedures described below.

Three percent $(\mathrm{v} / \mathrm{v})$ of pure glycerol, or crude or hydrolyzed glycerin were added to the production medium with 10.0 g. $\mathrm{L}^{-1}$ of ammonium sulfate and 0.5 g. $\mathrm{L}^{-1}$ of yeast extract as nitrogen sources. The production conditions used were the same as in the cashew apple juice experiments. Samples were collected at defined intervals of 24 hours and submitted to analysis for determination of glycerol, cell concentration, emulsification index and surface tension.

\section{Crude Glycerin}

The $\mathrm{pH}$ of crude glycerin was adjusted to 7.0 with $0.8 \mathrm{M} \mathrm{H}_{2} \mathrm{SO}_{4}$ in order to eliminate free alkalinity. After that, it was heated $\left(120^{\circ} \mathrm{C}\right)$ for $1 \mathrm{~h}$ under agitation for methanol elimination. The sodium sulfate produced from the neutralization was separated by decantation.

Table 1: Composition of CCAJ utilized as raw material for biosurfactant production by Y. lipolytica (Rocha et al., 2007).

\begin{tabular}{|l|r|}
\hline Parameters & CCAJ \\
\hline Glucose $\left(\mathrm{g} . \mathrm{l}^{-1}\right)$ & $43.67 \pm 0.30$ \\
Fructose $\left(\mathrm{g} . \mathrm{l}^{-1}\right)$ & $42.43 \pm 0.10$ \\
Soluble proteins $\left(\mathrm{mg} . \mathrm{ml}^{-1}\right)$ & $0.10 \pm 0.00$ \\
Total protein $\left(\mathrm{mg} . \mathrm{ml}^{-1}\right)$ & $5.19 \pm 0.00$ \\
Phosphorous $\left(\mathrm{g} . \mathrm{l}^{-1}\right)$ & $1.21 \pm 0.00$ \\
Potassium $\left(\mathrm{g} . \mathrm{l}^{-1}\right)$ & $13.13 \pm 0.90$ \\
Calcium $\left(\mathrm{g} . \mathrm{l}^{-1}\right)$ & $<\mathrm{DL}$ \\
Magnesium $\left(\mathrm{g} . \mathrm{l}^{-1}\right)$ & $1.17 \pm 0.10$ \\
Sodium $\left(\mathrm{g} . \mathrm{l}^{-1}\right)$ & $0.09 \pm 0.00$ \\
Sulfur $\left(\mathrm{g} . \mathrm{l}^{-1}\right)$ & $0.81 \pm 0.00$ \\
Copper $\left(\mathrm{mg} . \mathrm{l}^{-1}\right)$ & $<\mathrm{DL}$ \\
Iron $\left(\mathrm{mg} . \mathrm{l}^{-1}\right)$ & $6.97 \pm 2.70$ \\
Zinc $\left(\mathrm{mg} . \mathrm{l}^{-1}\right)$ & $11.20 \pm 4.30$ \\
Manganese $\left(\mathrm{mg} . \mathrm{l}^{-1}\right)$ & $6.40 \pm 0.40$ \\
\hline
\end{tabular}

$\mathrm{pH}=4.32 \pm 0.01 . * \mathrm{DL}=$ detection limit

Table 2: Composition of CCAJ media for biosurfactant production by Y. lipolytica

\begin{tabular}{|c|c|c|}
\hline Experiments & Carbon source & Nitrogen source \\
\hline $\mathbf{1}$ & CCAJ $1: 1^{\mathrm{a}}$ & -- \\
$\mathbf{2}$ & CCAJ $1: 1^{\mathrm{a}}$ & $10.0 \mathrm{~g} \cdot 1^{-1}\left(\mathrm{NH}_{4}\right)_{2} \mathrm{SO}_{4}$ \\
$\mathbf{3}$ & CCAJ $1: 10^{\mathrm{b}}$ & -- \\
$\mathbf{4}$ & CCAJ $1: 10^{\mathrm{b}}$ & $10.0 \mathrm{~g} \cdot 1^{-1}\left(\mathrm{NH}_{4}\right)_{2} \mathrm{SO}_{4}$ \\
\hline
\end{tabular}

${ }^{\mathrm{a}} \mathrm{CCAJ}$ was diluted one time with distilled water. ${ }^{\mathrm{b}} \mathrm{CCAJ}$ was diluted ten-fold with distilled water. 


\section{Hydrolyzed Glycerin}

Hydrolyzed glycerin was prepared by acid hydrolysis of crude glycerin as described in Sousa et al. (2011). The glycerin hydrolysis was conducted at room temperature with concentrated $\mathrm{H}_{2} \mathrm{SO}_{4}$. The volume of $\mathrm{H}_{2} \mathrm{SO}_{4}$ needed was determined by the total alkalinity of glycerin (Eq. (1)). Then, water was added to the system in the ratio of $1: 3$ with respect to the mass of glycerin. The hydrolysis was conducted in a separation funnel for $24 \mathrm{~h}$ to allow phase settling to occur (glycerin and fatty acid). The resulting hydrolyzed glycerin was used as the carbon source in batch experiments.

$\mathrm{V}_{\mathrm{H}_{2} \mathrm{SO}_{4}}=\frac{\mathrm{AT} \times \mathrm{m}}{\mathrm{N}}$

where $\mathrm{V}_{\mathrm{H} 2 \mathrm{SO} 4}$ is the volume of $\mathrm{H}_{2} \mathrm{SO}_{4}(\mathrm{~L})$, AT is the total alkalinity $\left(\mathrm{mg} . \mathrm{L}^{-1}\right), \mathrm{m}$ is the mass of glycerin $(\mathrm{mg})$ and $\mathrm{N}$ is the normality of $\mathrm{H}_{2} \mathrm{SO}_{4}$.

\section{Biosurfactant Extraction}

Biosurfactant extraction was adapted from the method described by Amaral et al. (2006). The culture medium was centrifuged $(26,000 \mathrm{x} g)$ at $25^{\circ} \mathrm{C}$ for $20 \mathrm{~min}$ and then filtered through a $0.45-\mu \mathrm{m}$ membrane (Millipore Corp.). Approximately $150 \mathrm{~mL}$ of the cell-free filtrate was transferred to a $3.6-\mathrm{ft}$ $(110-\mathrm{cm})$ length of dialysis tubing (diameter, $4 \mathrm{~cm}$; molecular cut-off, 12,000 Da) and concentrated to $25 \mathrm{~mL}$ by pervaporation. The concentrated crude extract $(25 \mathrm{~mL})$ was used for surfactant extraction in a $500 \mathrm{ml}$ separatory funnel at $25^{\circ} \mathrm{C}$. Three different solvent systems were used: concentrated crude extract/chloroform/methanol (1:1:1, 1:2:2, 1:4:4, 1:6:6 and $1: 8: 8, \mathrm{v} / \mathrm{v})$, concentrated crude extract/ acetone $(1: 3, \mathrm{v} / \mathrm{v})$, concentrated crude extract/ethyl acetate $(1: 2, \mathrm{v} / \mathrm{v})$. The concentrated crude extract and the solvents were shaken for five minutes and the white precipitate formed was centrifuged $(32,000 \times g)$ at $25^{\circ} \mathrm{C}$ for $30 \mathrm{~min}$, re-suspended in water and lyophilized.

\section{Surface Tension (ST)}

The surface tension was determined on cell-free broth, obtained by centrifugation at $1000 \mathrm{x} g$ for $10 \mathrm{~min}$, with a Tensiometer $\mathrm{K} 100$ (Kruss) using the ring method at room temperature $\left(25 \pm 2{ }^{\circ} \mathrm{C}\right)$. Surface tension was evaluated as a variation $(\Delta \mathrm{ST})$ between the initial surface tension (cell-free culture medium at the beginning of the experiment) and the final surface tension.

\section{Emulsification Index (EI)}

The emulsification index was determined by using a modification of the method described by Iqbal et al. (1995). The EI of cell-free samples was determined by adding $1 \mathrm{~mL}$ of hexadecane to the same amount of sample, vortex-mixing this mixture for $2 \mathrm{~min}$ and leaving it to stand for 24 hours. The EI is given as the percentage of height of the emulsified layer $(\mathrm{cm})$ divided by the total height of the liquid column $(\mathrm{cm})$.

\section{Cell Determination}

Cell concentration was followed by optical density measurements at $570 \mathrm{~nm}$ and the values were converted to $\mathrm{mg} / \mathrm{ml}$ using a factor previously determined (Amaral et al., 2006).

\section{Determination of Reducing Sugars}

Total reducing sugars were determined colorimetrically by the dinitrosalicylic acid (DNS) method (Miller, 1959).

\section{Glycerol Concentration}

Glycerol concentration was analyzed by enzymatic-colorimetric assay using a triglycerides kit (GPO/POD - CELM/Brazil).

\section{Determination of Total Carbon and Nitrogen}

The total carbon contents of the crude and hydrolyzed glycerin were measured by means of a dry combustion method (Shimadzu, TOC-V CPH/CPN). For total nitrogen determinations, the samples were digested with potassium persulfate and analysed by the method described for nitrate (Grasshoff, 1999).

\section{RESULTS AND DISCUSSION}

\section{Clarified Cashew Apple Juice (CCAJ) as Biosurfactant Production Medium}

Initially, biosurfactant production with CCAJ diluted with water (1:1) was evaluated without nitrogen source addition (exp.1) and with ammonium sulfate addition $(1 \% \mathrm{w} / \mathrm{v})(\exp .2)$ in sufficient amounts to obtain a molar carbon to nitrogen ratio $(\mathrm{C} / \mathrm{N})$ of 11.65 , which was previously shown to promote higher biosurfactant production (Fontes et al., 2010). Process parameters (cell concentration 
and reducing sugar concentration) were monitored during the experiment and the results are presented in Figure 1(a).

It was verified that, in the culture medium with CCAJ supplemented with ammonium sulfate, the cell growth level was higher, reaching $8.27 \mathrm{~g}$ dry weight of biomass per litter, whereas in the culture medium without nitrogen source addition biomass production was $6.21 \mathrm{~g}$ dry weight of biomass per litter. Similar results were found by Rocha et al. (2007), who evaluated cashew apple juice as raw material for Pseudomonas aeruginosa in submerse cultivation and observed a higher cell growth with the nitrogen source supplement because the juice presents low total and soluble protein concentration.

Concerning the reducing sugar consumption, a higher consumption rate was found in exp. 2 due to the availability of a nitrogen source. The reducing sugar was not totally consumed during the process, leaving approximately 13.0 g.L $\mathrm{L}^{-1}$ (exp.2) and 20.0 g.L $\mathrm{L}^{-1}$ (exp.1) after 96 hours of cultivation, which can possibly be attributed to the lack of nitrogen source at this point.

It was also verified that the $\mathrm{pH}$ in both experiments slowly decreased to 3.8 (exp.1) or 3.2 (exp.2) at 48 hours of the bioprocess, being practically constant beyond this point (data not shown).

Surface tension and emulsification index evolution throughout the experiments are presented in Figure 1(b), where it is possible to observe that $Y$. lipolytica was able to produce biosurfactant in culture medium containing CCAJ as raw material. The highest biosurfactant production was detected in the culture medium supplemented with ammonium sulfate, reaching an EI of $53.2 \%$ and a $\Delta \mathrm{ST}$ of $18.3 \mathrm{mN} . \mathrm{m}^{-1}$.

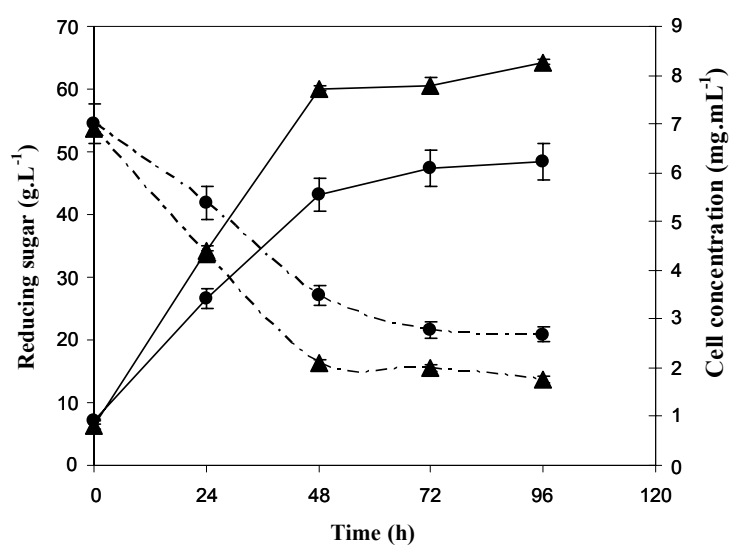

(a)
There was no significant surface tension reduction in the medium without nitrogen source addition, with a $\Delta \mathrm{ST}$ of only $11.7 \mathrm{mN} . \mathrm{m}^{-1}$ and an EI of $40.1 \%$. According to Rocha et al. (2007), the biosurfactant production by $P$. aeruginosa occurred with ten-fold diluted cashew apple juice as carbon source supplemented with nitrogen source. In order to test this condition, ten-fold diluted CCAJ without nitrogen source addition (exp.3) and with ammonium sulfate $1 \% \mathrm{w} / \mathrm{v}$ (exp.4) was used for biosurfactant production by $Y$. lipolytica, like Rocha et al. (2007).

Figure 2(a) presents the results for the cell growth profile and the total reducing sugar consumption. The cell growth profile was different from that obtained with 1:1 diluted cashew apple juice. In $48 \mathrm{~h}$ of cultivation the cells were still in the exponential phase of growth, entering the stationary phase only after $72 \mathrm{~h}$ of the process. On the other hand, Rocha et al. (2007) observed a stationary phase of growth for $P$. aeruginosa within 30 and $25 \mathrm{~h}$, respectively. The maximum biomass concentration obtained was slightly lower than that achieved with 1:1 diluted medium, as well as the specific growth rate, which can be seen in Table 3 .

The reducing sugar was practically all consumed in $48 \mathrm{~h}$ on both experiments. A higher sugar consumption rate was detected in comparison to the medium diluted 1:1 (Table 3).

Figure (2b) presents the results for biosurfactant production by $Y$. lipolytica with ten-fold diluted CCAJ. Both culture media evaluated seem to favor biosurfactant production, which was estimated by the EI and the surface tension reduction. The highest $\Delta$ ST $\left(24.3 \mathrm{mN} \cdot \mathrm{m}^{-1}\right)$ and EI $(65.0 \%)$ were obtained in exp. 4 , which contained $1.0 \%$ ammonium sulfate.

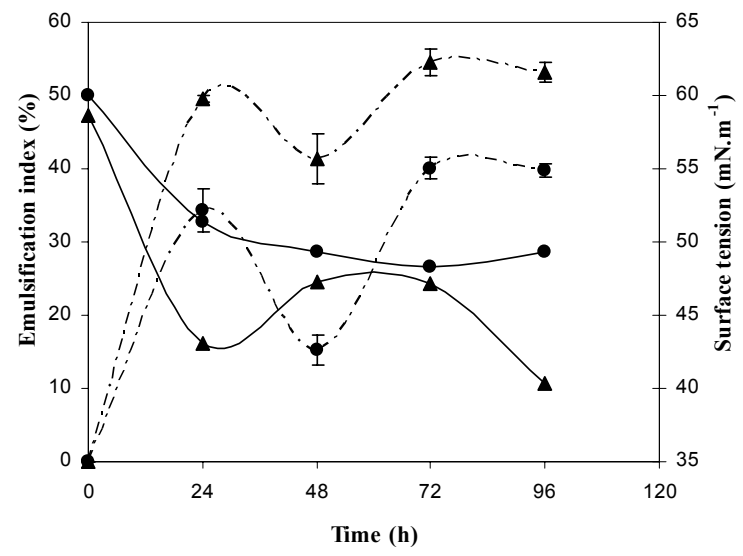

(b)

Figure 1: (a) Reducing sugar consumption (---) and cell growth profiles (-) of $Y$. lipolytica. (b) Emulsification index (---) and surface tension (-) of the cell-free broth of Y. lipolytica grown in CCAJ diluted 1:1 without nitrogen source addition (exp.1 •) and with ammonium sulfate addition $(1.0 \% \mathrm{w} / \mathrm{v})$ $(\exp .2 \Delta)$. 


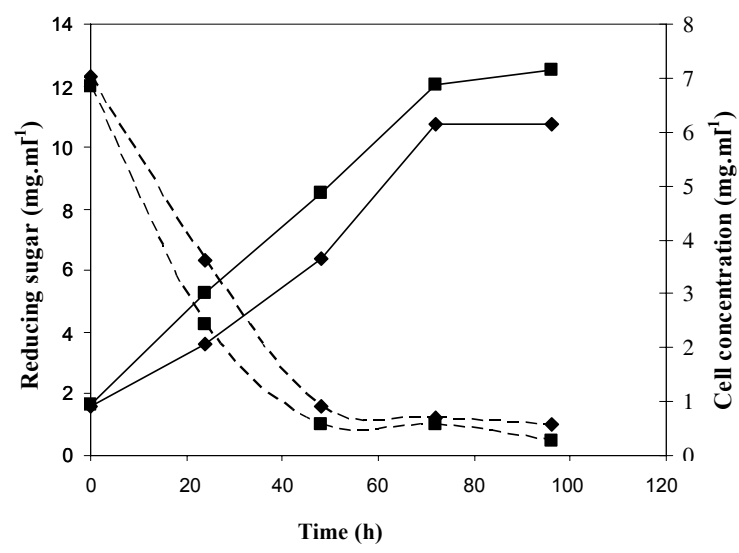

(a)

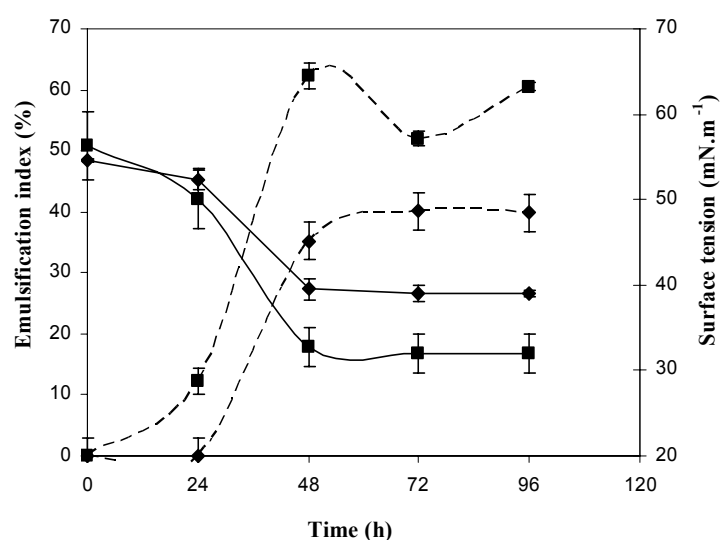

(b)

Figure 2: (a) Reducing sugar consumption (--) and (-) cell growth profiles of Y. lipolytica. (b) Emulsification index (---) and surface tension (-) of biosurfactant produced by Y. lipolytica grown in CCAJ diluted 1:10 without nitrogen source (exp.3 ) and supplemented with ammonium sulfate $(1.0 \% \mathrm{w} / \mathrm{v})$ (exp.4匹).

Table 3: Parameters for biosurfactant production by Y. lipolytica with CCAJ.

\begin{tabular}{|c|c|c|c|c|}
\hline \multirow{2}{*}{ Parameter } & \multicolumn{2}{|c|}{ CCAJ 1:1 diluted } & \multicolumn{2}{|c|}{ CCAJ 1:10 diluted } \\
\hline & Exp.1 & Exp.2 & Exp.3 & Exp.4 \\
\hline$\mu\left(h^{-1}\right)$ & 0.07 & 0.05 & 0.03 & 0.03 \\
\hline$-\mathrm{dS} / \mathrm{dt}\left(\mathrm{g} .(\mathrm{l} . \mathrm{h})^{-1}\right)$ & 0.58 & 0.78 & 0.24 & 0.22 \\
\hline$\Delta S T\left(m N \cdot m^{-1}\right)$ & 11.68 & 18.28 & 12.55 & 24.33 \\
\hline EI $(\%)$ & 40.10 & 53.18 & 40.11 & 65.00 \\
\hline $\mathrm{X}_{\mathrm{f}}\left(\mathrm{mg} \cdot \mathrm{ml}^{-1}\right)$ & 6.21 & 8.27 & 6.15 & 7.15 \\
\hline
\end{tabular}

$\mu$ : specific growth rate

-dS/dt: sugar consumption rate

$\triangle \mathrm{ST}$ : surface tension variation

EI: Emulsification index

$\mathrm{X}_{\mathrm{f}}$ : final cell concentration

The culture medium without nitrogen source addition failed to provide a significant surface tension reduction $\left(12.5 \mathrm{mN} . \mathrm{m}^{-1}\right)$ or a good value for EI (40.1\%), very similar to exp.1 (Table 3). According to Willumsen and Karlson (1996), a biosurfactant with good emulsifier properties presents an EI over 50.0\%. These results show the importance of nitrogen source supplement for biosurfactant production in CCAJ medium. Although the majority of microorganisms produce biosurfactant under limiting nitrogen conditions (Willumsen and Karlson, 1996), a sufficient initial amount of nitrogen is required and the type and quantity of this component vary according to the microorganism used.

According to Rocha et al. (2007), P. aeruginosa was able to reduce the surface tension of cashew apple juice medium from 50 to $29.5 \mathrm{mN} . \mathrm{m}^{-1}$ using peptone $\left(5.0\right.$ g. $\left.\mathrm{L}^{-1}\right)$ as nitrogen source. When the authors used ammonium sulfate (5.0 g.L $\left.{ }^{-1}\right)$ and
$\mathrm{NaNO}_{3}\left(5.0\right.$ g.L $\left.{ }^{-1}\right)$, biosurfactant production was not favored.

Biosurfactant production by Acinetobacter calcoaceticus, using natural cashew apple juice and a mineral complex medium was evaluated by Rocha et al. (2006). The authors observed that the maximum EI value reached was $58.8 \%$, lower then the one obtained in the present work. The surface tension reduction was not significant (from 70.0 to $63.0 \mathrm{mN} . \mathrm{m}^{-1}$ ) during the experiments. Contrary to what was observed in this work, biosurfactant production occurred only during the stationary phase growth, as a typical secondary metabolite.

Diluted cashew apple juice was not an adequate substrate for the growth of a Bacillus subtilis strain, because no biomass or biosurfactant were produced when this microorganism was cultivated on this medium. Only when ammonium sulfate was added was cell growth observed, but no significant surface

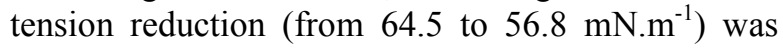


achieved (Rocha et al., 2006). Therefore, in the present work, a higher surface tension variation was obtained $\left(24.3 \mathrm{mN} \cdot \mathrm{m}^{-1}\right)$.

According to the results, diluted cashew apple juice $(1: 10)$ supplemented with ammonium sulfate $(1.0 \%)$ provided a better biosurfactant production (Table 3) in relation to cashew apple juice diluted $1: 1$.

In order to recover the biosurfactant from the fermentation medium, three types of solvent systems were tested. Several organic solvents can be used and they are used either singly or in combination for biosurfactant extraction (Ashby et al., 2005). Based on the amount of biosurfactant recovered in the extract from cell-free medium, the results indicate that a mixture of chloroform and methanol in the ratio 1:8:8 (6.85 $\mathrm{g}$ of biosurfactant. $\left.\mathrm{L}^{-1}\right)$ was the best system for the extraction compared to acetone $(0.33 \mathrm{~g}$ of biosurfactant. $\left.\mathrm{L}^{-1}\right)$ or ethyl acetate $(0.09 \mathrm{~g}$ of biosurfactant. $\mathrm{L}^{1}$ ). Mixtures of solvents are commonly used to facilitate adjustment of the polarity between the solvent or extraction agent and the biosurfactant to be extracted.

\section{Glycerin as Fermentation Medium for Biosurfactant Production}

The glycerin phase composition resulting from biodiesel production varies largely considering the transesterification process and the efficiency of biodiesel separation. Therefore, the crude and hydrolyzed glycerin used in this work were first characterized in terms of glycerol concentration, total carbon, total nitrogen and $\mathrm{pH}$. Table 4 presents the main parameters evaluated for the crude and hydrolyzed glycerin samples.

\section{Table 4: Glycerin composition}

\begin{tabular}{|c|c|c|}
\hline Parameter & $\begin{array}{c}\text { Crude } \\
\text { glycerin }\end{array}$ & $\begin{array}{l}\text { Hydrolyzed } \\
\text { glycerin }\end{array}$ \\
\hline Glycerol concentration $\left(\mathrm{g} . \mathrm{I}^{-1}\right)$ & $729.5 \pm 0.3$ & $741.9 \pm 0.2$ \\
\hline Total carbon $\left({\left.\mathrm{g} . \mathrm{I}^{-1}\right)}^{-1}\right.$ & $310.3 \pm 0.1$ & $292.8 \pm 0.1$ \\
\hline Total nitrogen $\left(\mathrm{g.l} \mathrm{I}^{-1}\right)$ & $\mathrm{ND}^{*}$ & ND* \\
\hline
\end{tabular}

*ND not detected, $\mathrm{pH}=6.0 \pm 0.1$

Both crude and hydrolyzed glycerin present high glycerol and total carbon concentrations, which are essential for biosurfactant production and cell growth. The $\mathrm{pH}$ of both samples after correction was 6.0 ; the $\mathrm{pH}$ of the glycerin phase without correction was 13.0, which is a very alkaline value for microbial growth. Total nitrogen was not detected in either sample, being lower than $1.4 \mu \mathrm{g}$ of nitrogen. $\mathrm{L}^{-1}$ (limit for detection). Hence, because a nitrogen source is essential for cell growth and biosurfactant production, the medium with glycerin phase as substrate was supplemented with ammonium sulfate 10.0 g. $\mathrm{L}^{-1}$ and yeast extract 0.5 g.L $\mathrm{L}^{-1}$. Pure, crude and hydrolyzed glycerol were all used at a concentration of $3.0 \%(\mathrm{v} / \mathrm{v})$.

Figure 3(a) presents the growth kinetics profiles of $Y$. lipolytica on the media tested. Cell growth was higher when crude glycerin was used as substrate. This result can be attributed to the fatty acid present in the crude glycerin phase as an additional carbon source, increasing cell growth. According to Ashby et al. (2005), the residue of biodiesel synthesis from soy oil contains $40.0 \%$ of glycerol, $34.0 \%$ of compounds soluble on hexane (made up of $92.0 \%$ free fatty acid/fatty acid methyl esters and $6.0 \%$ of monoacyl glycerol e diacyl glycerol) and $26.0 \%$ water. After $96 \mathrm{~h}$ the biomass produced in the experiments with crude, pure and hydrolyzed glycerin was $12.0 ; 9.0$; and 7.5 g. $\mathrm{L}^{-1}$, respectively. Similar results were obtained by Ashby et al. (2005), with a higher cell growth for Candida bombicola with biodiesel production byproduct $(4.0 \%)$ than with pure glycerol $(10.0 \% \mathrm{v} / \mathrm{v})$.

In Figure 3(b), it is possible to observe that glycerol consumption by the yeast was similar for the three types of glycerin. At the end of the experiment $(96 \mathrm{~h})$, glycerol was practically all consumed in all experiments.

Glycerol is typically transported to the cell through the membrane by facilitated diffusion over a concentration gradient and then quickly converted to glycerol-3-phosphate by glycerol kinase and subsequently oxidized to dihydroxyacetone phosphate (DHAP), a common glycolytic pathway intermediate, by glycerol phosphate dehydrogenase. DHAP is enzymatically transformed to its isomer glyceraldehyde-3-phosphate (G3P) and both can be converted to glucose by gluconeogenesis and subsequently to the sugars present in the biosurfactant structure or can be directed to cellular growth. Alternatively, G3P can be converted to pyruvate for subsequent conversion to acetyl-CoA, the main metabolic precursor for fatty acid biosynthesis (Lehninger, 2006).

Figure 4 shows the evolution of the surface tension and the emulsification index for the experiments with glycerin. For both methods used to verify the presence of a biosurfactant being excreted into the culture medium, the higher production occurred in the culture media containing crude glycerin, reaching an EI of $70.2 \%$ and a $\Delta$ ST of $22.0 \mathrm{~N} \cdot \mathrm{m}^{-1}$ after $96 \mathrm{~h}$. 


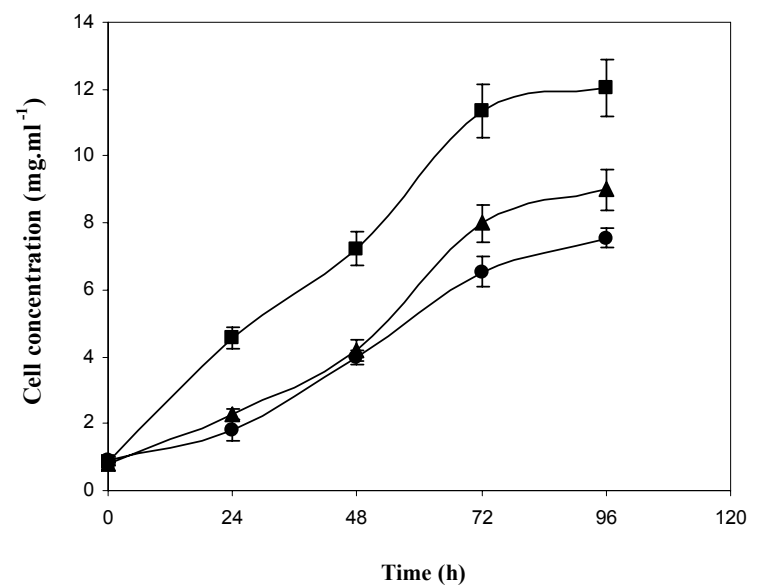

(a)

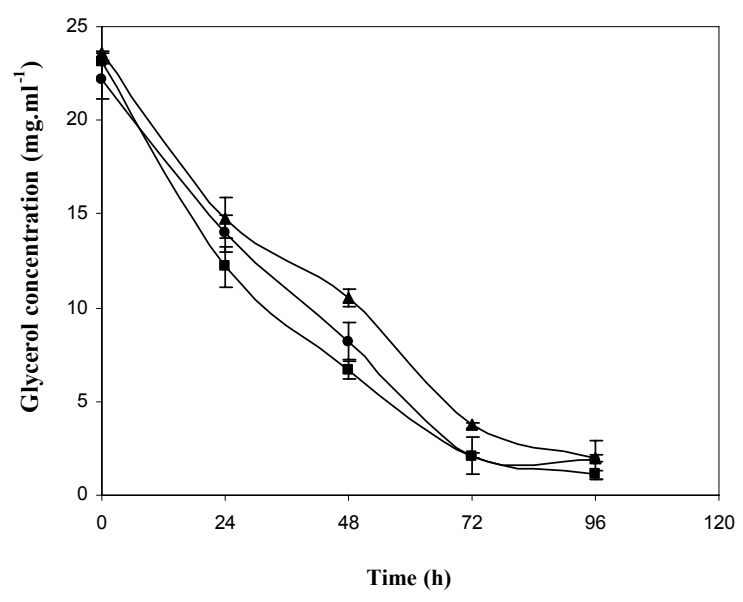

(b)

Figure 3: Time-course of cell growth (a) and glycerol consumption (b) by Y. lipolytica using pure ( $\mathbf{\Lambda}$ ), crude $(\bullet)$ and hydrolyzed $(\bullet)$ glycerin as carbon source.

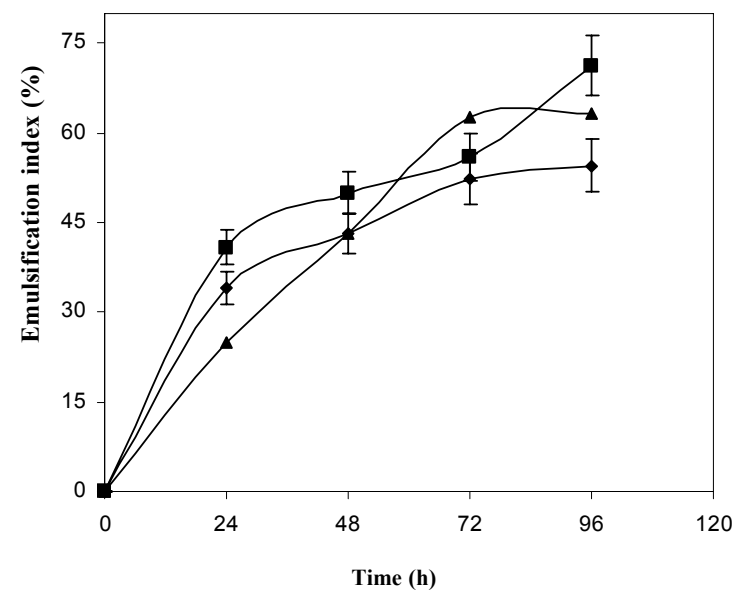

(a)

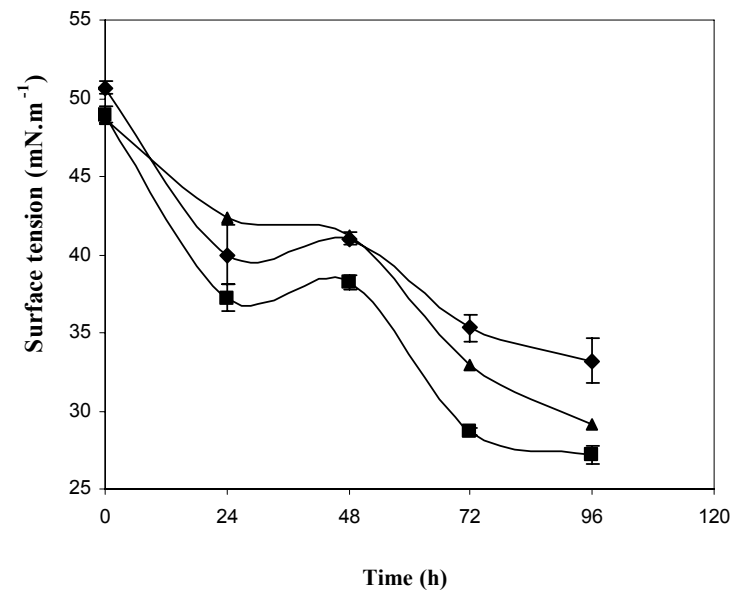

(b)

Figure 4: Emulsification index (a) and surface tension (b) for biosurfactant produced by Y. lipolytica cultivated in pure $(\mathbf{\Lambda})$, crude $(\boldsymbol{\bullet})$ and hydrolyzed $(\bullet)$ glycerol as carbon source.

The fact that biosurfactant production is higher in the medium containing crude glycerin can be attributed to the presence of fatty acids. According to Weber et al. (1992), Candida (Yarrowia) species are able to incorporate fatty acid directly for biosurfactant production. While glycerol is mainly used for cell growth and production of the hydrophilic portion biosurfactant molecule production, fatty acids present on crude glycerin are used by the cell directly for biosurfactant production. This way, the biosurfactant lipidic portion can be influenced by the type of oil used for biodiesel production. It is important to point out that, during the experiments with crude glycerin the foam formation was less intense when compared to the culture medium containing pure or hydrolyzed glycerin.
Souza et al. (2011) studied biosurfactant production by $P$. aeruginosa using the glycerin $(6.0 \%)$ obtained from a biodiesel production process as carbon source and sodium nitrate as nitrogen source. The authors obtained $64.0 \%$ of EI and a reduction in surface tension of $45.7 \%$. Higher EI values were obtained in the present work with $Y$. lipolytica and crude glycerin $(71.2 \%)$ and a similar surface tension reduction.

The biosurfactant extraction was performed in culture media containing crude glycerol as carbon source because it showed better emulsification index values and a greater surface tension variation. The ability of solvents to extract the biosurfactant produced by $Y$. lipolytica was evaluated using different extraction systems: concentrated extract/chloroform/ methanol $(1: 8: 8, \mathrm{v} / \mathrm{v})$, concentrated extract/acetone $(1: 3, \mathrm{v} / \mathrm{v})$, concentrated extract/ethyl acetate $(1: 2, \mathrm{v} / \mathrm{v})$. 
The results presented in Figure 5 show that chloroform/methanol was the best system for the extraction, as was observed for the extraction of the biosurfactant produced with CCAJ. This result can be attributed to the hydrophobic/ hydrophilic balance of the chloroform/methanol solvent system.

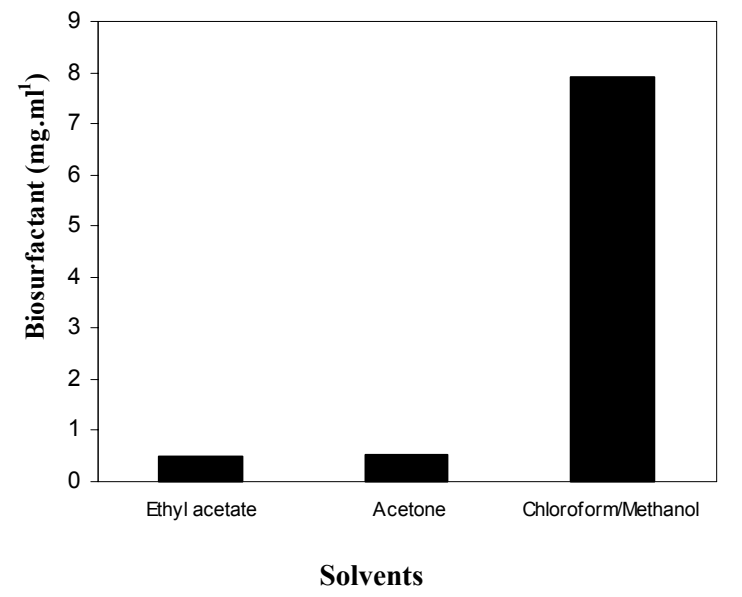

Figure 5: Biosurfactant extraction using different solvent systems.

In order to investigate the influence of solvent proportion on biosurfactant extraction from the concentrated extract, five different concentrated extract/chloroform/methanol ratios were used: $1: 1: 1$; $1: 2: 2 ; 1: 4: 4 ; 1: 5: 5 ; 1: 8: 8$. The results show that the best ratio was $1: 8: 8$, which promoted an extraction of $7.90 \mathrm{~g}$ of biosurfactant per $1000 \mathrm{~mL}$ of concentrated cell-free medium (Figure 6). This is a significant value when compared to the amount obtained by Sheperd et al. (1995) for biosurfactant produced by Candida utilis in the presence of corn oil $\left(0.9 \mathrm{~g} . \mathrm{l}^{-1}\right)$. Table 5 show the amount of biosurfactant produced by different yeasts.

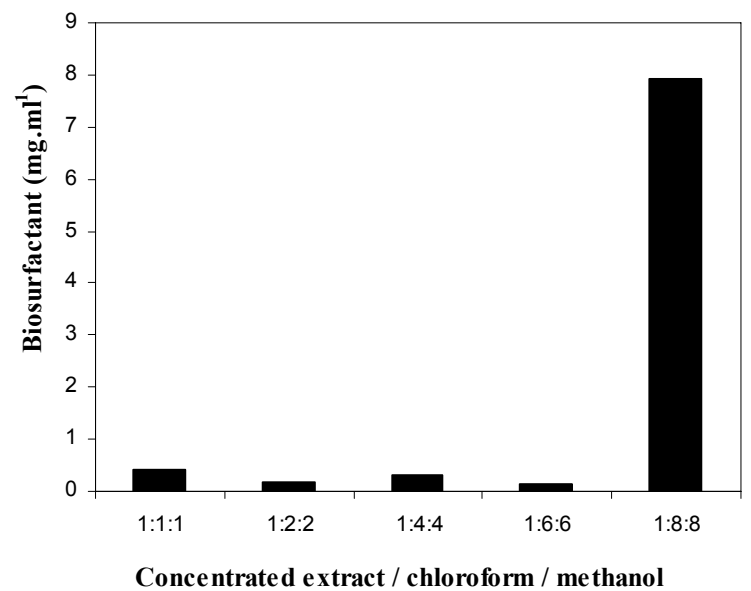

Figure 6: Biosurfactant extraction using chloroform/ methanol.
Table 5: Amount of biosurfactant produced by different yeasts.

\begin{tabular}{|c|c|c|c|}
\hline Micoorganism & $\begin{array}{c}\text { Carbon } \\
\text { source }\end{array}$ & $\begin{array}{c}\text { Biosurfactant } \\
\left(\mathrm{g.l}^{-1}\right)\end{array}$ & Reference \\
\hline $\begin{array}{l}\text { Yarrowia } \\
\text { lipolytica }\end{array}$ & $\begin{array}{l}\text { Crude } \\
\text { Glycerin }\end{array}$ & 7.9 & Present work \\
\hline $\begin{array}{l}\text { Yarrowia } \\
\text { lipolytica }\end{array}$ & $\begin{array}{l}\text { Cashew } \\
\text { apple juice }\end{array}$ & 6.9 & Present work \\
\hline $\begin{array}{l}\text { Candida } \\
\text { lipolytica }\end{array}$ & $\begin{array}{l}\text { Canola oil/ } \\
\text { Glucose }\end{array}$ & 8.0 & $\begin{array}{l}\text { Sarubbo et al. } \\
(2007)\end{array}$ \\
\hline $\begin{array}{l}\text { Candida } \\
\text { sphaerica }\end{array}$ & $\begin{array}{c}\text { Ground-nut oil } \\
\text { refinery residue }\end{array}$ & 4.5 & $\begin{array}{l}\text { Sobrinho et al. } \\
\text { (2008) }\end{array}$ \\
\hline $\begin{array}{l}\text { Candida } \\
\text { lipolytica }\end{array}$ & $\begin{array}{l}\text { Industrial } \\
\text { waste }\end{array}$ & 4.5 & $\begin{array}{l}\text { Rufino et al. } \\
(2007)\end{array}$ \\
\hline $\begin{array}{l}\text { Candida } \\
\text { glabrata }\end{array}$ & $\begin{array}{l}\text { Cotton seed } \\
\text { oil /glucose }\end{array}$ & 10.0 & $\begin{array}{l}\text { Sarubbo et al. } \\
(2006)\end{array}$ \\
\hline $\begin{array}{l}\text { Candida } \\
\text { antarctica }\end{array}$ & soapstock & 15.9 & $\begin{array}{l}\text { Bednarski et al. } \\
\text { (2004) }\end{array}$ \\
\hline $\begin{array}{l}\text { Candida } \\
\text { utilis }\end{array}$ & Corn oil & 0.9 & $\begin{array}{l}\text { Sheperd et al. } \\
\text { (1995) }\end{array}$ \\
\hline
\end{tabular}

\section{CONCLUSIONS}

The results indicate that $Y$. lipolytica was able to grow and produce biosurfactant when cultivated in all the media studied. This study shows that traditional carbon sources for biosurfactant production can be replaced by residual glycerol or CCAJ. The increasing biodiesel production generates large amounts of crude glycerin, which could be successfully used as a carbon source for biosurfactant production, as demonstrated by the results present in this manuscript. Similarly, the use of CCAJ as a culture medium would provide waste management alternative for the productive chain of cashew nut, an important industrial segment on the Northeast of Brazil.

\section{ACKNOWLEDGEMENTS}

The authors kindly acknowledge financial aid and research scholarships given by CAPES, CNPq and FAPERJ.

\section{REFERENCES}

Amaral, P. F. F., Da Silva, J. M., Lehocky, B. M., Barros-Timmons, A. M. V., Coelho, M. A. Z., Marrucho, I. M. and Coutinho, J. A. P., Production and characterization of a bioemulsifier from Yarrowia lipolytica. Process. Biochem., 41, 1894-1898 (2006).

Amaral, P. F. F., Ferreira, T. F., Fontes, G. C. and

Coelho, M. A. Z., Glycerol valorization: New 
biotechnological routes. Food Bioprod. Process., 87, 179-186 (2009).

Ashby, R. D., Nuñez, A., Solaiman, D. K. Y. and Foglia, T. A., Sophorolipid biosynthesis from a biodiesel co-product stream. J. Am. Oil. Chem. Soc., 82, 625-630 (2005).

Bednarski, W., Adamczk, M., Tomasik, J. and Plszczyk, M., Application of oil refinery waste in the biosynthesis of glycolipids by yeast. Bioresour. Technol., 95, 15-18 (2004).

Campos, D. C. P., Santos, A. S., Wolkoff, D. B., Matta, V. M., Cabral, L. M. C. and Couri, S., Cashew apple juice stabilization by microfiltration. Desalination, 148, 61-65 (2002).

Ciapina, E. M. P., Melo, W. C., Santanna, L. M. M., Santos, A. S., Freire D. M. G. and Pereira, N. J., Biosurfactant production by Rhodococcus erythropolis grown on glycerol as sole carbon source. Appl. Biochem. Biotechnol., 131, 880886 (2007).

Desphande, M. and Daniels, L., Evaluation of sophorolipid biosurfactant production by Candida bombicola using animal fat. Bioresour. Technol., 54, 143-150 (1995).

Dubey, K. and Juwarkar, A., Distillery and curd whey wastes as viable alternative sources for biosurfactant production. World J. Microbiol. Biotechnol., 17, 61-69 (2001)

Fontes, G. C., Amaral, P. F. F., Nele, M. and Coelho, M. A. Z., Factorial design to optimize biosurfactant production by Yarrowia lipolytica. J. Biomed. Biotechnol., 2010, 1-8 (2010).

Grasshoff, K., Kremling, K. and Erhardt, M., Methods of Seawater Analysis, 3rd Ed. Weinheim, Germany: Wiley-VCH-Verlag (1999).

Haegler, A. N. and Mendonça-Haegler, L. C., Yeast from marine and estuarine waters with different levels of pollution in the State of Rio de Janeiro, Brazil. Appl. Environ. Microbiol., 41, 173-178 (1981).

Honorato, T. L., Rabelo, M. C., Gonçalves, L. R. B., Saavedra, G. A. and Rodrigues, S., Fermentation of cashew apple juice to produce high added value products. World J. Microbiol. Biotechnol., 23, 1409-1415 (2007).

Hoogendoorn, A., Adriaans, T., van Kasteren, J. M. N., Jayaraj, K. M., Glycerine purification via bio-catalysis and column adsorption for high quality Applications, Report available from http://www.ingenia.nl/Flex/Site/Download.aspx?I $\mathrm{D}=2014$ [Electronic], (2007).

Iqbal, S., Khalid, Z. M. and Malik, K. A., Enhanced biodegradation and emulsification of crude oil and hyperproduction of biosurfactants by gamma ray-induced mutant of Pseudomonas aeruginosa. Lett. Appl. Microbiol., 21, 176-179 (1995).

Lehninger, A., Nelson, D. L. and Cox, M. M., Princípios de bioquímica, 4 Ed. Sarvier, São Paulo (2006).

Maneerat, S., Production of biosurfactants using substrates from renewable-resources. J. Sci. Technol., 27, 675-683 (2005).

Makkar, R. S. and Cameotra, S. S., Utilization of molasses for biossurfactante production by two Bacillus strains at thermophilic conditions. J. Am. Oil. Chem. Soc., 74, 887-889 (1997).

Mariano, A. P. Bonotto, D. M. Angelis, D. F., Pirôllo, M. P. S. and Contiero, J., Use of weathered diesel oil as a low-cost raw material for biosurfactant production. Braz. J. Chem. Eng., 25, 2, 269-274 (2008).

Mercade, M. E. and Mansera, M. A, The use of agroindustrial by-products for biosurfactant production. J. Am. Oil. Chem. Soc., 71, 61-64 (1994).

Miller, G. L., Use of dinitro salicylic acid reagent for determination of reducing sugar. Anal. Chem., 31, 426-428 (1959).

Morita, T., Konishi, M. Fukuoka., T., Imura, T. and Kitamoto, D., Microbial conversion of glycerol into glycolipid biosurfactants, mannosylerythritol lipids, by a basidiomycete yeast, Pseudozyma antarctica JCM 10317T. J. Biosci. Bioeng., 104, 78-81 (2007).

Mulligan, C. N., Environmental applications for biosurfactants. Environ. Pollut., 133, 183-198 (2004).

Muthusamy, K., Gopalakrishnan, S., Ravi, T. K. and Sivachidambaram, P., Biosurfactants: Properties, commercial production and application. Curr. Sci., 94, 736-747 (2008).

Nitschke, M. and Pastore, G. M., Biosurfactants: Properties and Applications. Quim. Nova, 25, 772-776 (2002).

Papanikolaou, S. and Aggelis, G., Modelling aspects of the biotechnological valorization of raw glycerol: Production of citric acid by Yarrowia lipolytica and 1,3 propanediol by Clostridium butyricum. J. Chem. Technol. Biotechnol., 78, 542-547 (2003).

Rocha, M. V. P., Oliveira, A. H. S., Souza, M. C. M. and Gonçalves, L. R. B., Natural cashew apple juice as fermentation medium for biosurfactant production by Acinetobacter calcoaceticus. World J. Microbiol. Biotechnol., 22, 1295-1299 (2006).

Rocha, M. V. P., Souza, M. C. M., Benedicto, S. C. L., Bezerra, M. S., Macedo, G. R., Pinto, G. A. S. 
and Gonçalves, L. R. B., Production of biosurfactant by Pseudomonas aeruginosa grown on cashew apple juice. Appl. Biochem. Biotechnol., 137, 185-194 (2007).

Rocha, M. V. P., Barreto, R. V. G., Melo, V. M. M., Gonçalves, L. R. B. Evaluation of cashew apple juice for surfactin production by Bacillus subtilis lami008. Appl. Biochem. Biotechnol., 155, 366378 (2009).

Rufino, R. D. L., Sarubbo, A. and Campos-Takaki, G. M., Enhancement of stability of biosurfactant produced by Candida lipolytica using industrial residue as substrate. World J. Microbiol. Biotechnol., 23, 729-734 (2007).

Sarubbo, L. A., Luna, J. M. and Campos-Takaki, G. M., Production and stability studies of the bioemulsifier obtained from a new strain of Candida glabrata UCP 1002. Electron. J. Biotechnol., 9, 400-406 (2006).

Sarubbo, L. A., Farias, C. B. B. and Campos-Takaki, G. M., Co-utilization of canola oil and glucose on the production of a surfactant by Candida lipolytica. Curr. Microbiol., 54, 68-73 (2007).

Sheperd, R., Rockey, J., Sutherland, I. and Roller, S., Novel bioemulsifiers from microorganisms for use in foods. J. Biotechnol., 40, 207-217 (1995).

Sobrinho, H. B. S., Rufino, R. D., Luna, J. M., Salgueiro, A. A., Campos-Takaki, G. M., Leite, L. F. C. and Sarubbo, L. A., Utilization of two agroindustrial by-products for the production of a surfactant by Candida sphaerica UCP0995. Process Biochem., 43, 912-917 (2008).
Souza, F. A. S. D., Salgueiro, A. A. and Albuquerque, C. D. C. Production of bioemulsifiers by Yarrowia lipolytica in sea water using diesel oil as the carbon source. Braz. J. Chem. Eng., 29, 61-67 (2012).

Sousa, J. R., Correia, J. A. C, Almeida, J. G. L., Rodrigues, S., Pessoa, O. D. L., Melo, V. M. M. and Gonçalves, L. R. B., Evaluation of a co-product of biodiesel production as carbon source in the production of biosurfactant by P. aeruginosa MSIC02. Process Biochem., 46, 1831-1839 (2011).

Vedaraman, N. and Venkatesh, N., Production of surfactin by bacillus subtilis mtcc 2423 from waste frying oils. Braz. J. Chem. Eng., 28, 2, 175180 (2011).

Weber, L., Doge, C. and Haufe, G., Oxygenation of hexadecane in the biosynthesis of cyclic glycolipids in Torulopsis apicola. Biocatalysis, 5, 267-272 (1992).

Wei, Y. H., Chou, C. L. and Chang, J. S., Rhamnolipid production by indigenous Pseudomonas aeruginosa J4 originating from petrochemical wastewater. Bioch. Eng. J., 27, 146-154 (2005).

Willumsen, P. A. and Karlson, U., Screening of bacteria, isolated from PAH-contaminated soils, for production of biosurfactants and bioemulsifiers. Biodegradation, 7, 415-423 (1996).

Wu, J. Y., Yeh, K. L., Lu, W. B., Lin, C. L. and Chang, J. S., Rhamnolipid production with indigenous Pseudomonas aeruginosa EM1 isolated from oil-contaminated site. Bioresour. Technol., 99, 1157-1164 (2008). 